\title{
CANDID SCIENCE III
}

More Conversătions with Famous Chemists 


\section{Also by the same author}

The Road to Stockholm: Nobel Prizes, Science, and Scientists, Oxford University Press, Oxford, 2002.

Candid Science II: Conversations with Famous Biomedical Scientists, Imperial College Press, London, 2002.

Candid Science: Conversation with Famous Chemists, Imperial College Press, London, 2000.

In Our Own Image: Personal Symmetry in Discovery (with M. Hargittai), Kluwer/Plenum, New York, 2000.

Upptäck Symmetri! (Discover Symmetry!, in Swedish, with M. Hargittai), Natur och Kultur, Stockholm, 1998.

Symmetry through the Eyes of a Chemist (with M. Hargittai), Second edition, Plenum, New York, 1995.

Symmetry: A Unifying Concept (with M. Hargittai), Shelter Publications, Bolinas, CA, 1994.

The VSEPR Model of Molecular Geometry (with R.J. Gillespie), Allyn \& Bacon, Boston, 1991.

The Structure of Volatile Sulphur Compounds, Kluwer/Reidel, Dordrecht, 1985.

The Molecular Geometries of Coordination Compounds in the Vapour Phase (with M. Hargittai), Elsevier, Amsterdam, 1977.

\section{Forthcoming}

Candid Science IV: Conversations with Famous Physicists (with M. Hargittai), Imperial College Press, London.

\section{Edited books}

Symmetry 2000 (with T.C. Laurent), Vols. I, II, Portland Press, London, 2002.

Strength from Weakness: Structural Consequences of Weak Interactions in Molecules,

Supermolecules, and Crystals (with A. Domenicano), Kluwer, Dordrecht, 2002.

Advances in Molecular Structure Research (with M. Hargittai), Vols. 1-6, JAI Press,

Greenwich, CT, 1995-2000.

Combustion Efficiency and Air Quality (with T. Vidóczy), Plenum, New York, 1995.

Spiral Symmetry (with C.A. Pickover), World Scientific, Singapore, 1992.

Fivefold Symmetry, World Scientific, Singapore, 1992.

Accurate Molecular Structures (with A. Domenicano), Oxford University Press, Oxford, 1992.

Quasicrystals, Networks, and Molecules of Fivefold Symmetry, VCH, New York, 1990.

Symmetry 2: Unifying Human Understanding, Pergamon Press, Oxford, 1989.

Stereochemical Applications of Gas-Phase Electron Diffraction (with M. Hargittai),

Vols. A, B, VCH, New York, 1988.

Crystal Symmetries, Shubnikov Centennial Papers (with B.K. Vainshtein), Pergamon

Press, Oxford, 1988.

Symmetry: Unifying Human Understanding, Pergamon Press, Oxford, 1986.

Diffraction Studies on Non-Crystalline Substances (with W. J. Orville-Thomas), Elsevier, Amsterdam, 1981. 


\section{CANDID SCIENCE III}

\section{More Conversations with Famous Chemists}

\section{István Hargittai}

Edited by Magdolna Hargittai 
Published by

Imperial College Press

57 Shelton Street

Covent Garden

London WC2H 9HE

\section{Distributed by}

World Scientific Publishing Co. Pte. Ltd.

5 Toh Tuck Link, Singapore 596224

USA office: Suite 202, 1060 Main Street, River Edge, NJ 07661

UK office: 57 Shelton Street, Covent Garden, London WC2H 9HE

\section{István Hargittai}

Budapest University of Technology and Economics

Eötvös University and Hungarian Academy of Sciences

H-1521 Budapest, Hungary

Magdolna Hargittai

Eötvös University and Hungarian Academy of Sciences

H-1518 Budapest, Pf. 32, Hungary

\section{British Library Cataloguing-in-Publication Data}

A catalogue record for this book is available from the British Library.

\section{CANDID SCIENCE III \\ More Conversations with Famous Chemists}

Copyright ( 2003 by István Hargittai

All rights reserved. This book, or parts thereof, may not be reproduced in any form or by any means, electronic or mechanical, including photocopying, recording or any information storage and retrieval system now known or to be invented, without written permission from the Publisher.

For photocopying of material in this volume, please pay a copying fee through the Copyright Clearance Center, Inc., 222 Rosewood Drive, Danvers, MA 01923, USA. In this case permission to photocopy is not required from the publisher.

ISBN 1-86094-336-5

ISBN 1-86094-337-3 (pbk) 


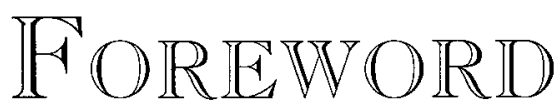

It has been a good many years since I read my first book on the history of science. Although I no longer remember the author or title of that book, I do remember the impression it made on me. First, it awakened in me a deep and abiding interest in science, an interest which has endured and become ever more intense with the passage of time. Then too, it has inspired me to read other books on the history of science and these in turn, as in a chain reaction, impelled me to read far more of science history than I could possibly absorb. Admittedly then, much of what I read in those early years was beyond my comprehension; however, over time, understanding eventually did follow.

There was one facet of this early activity which I found particularly fascinating and rewarding. This was the aspect of science history which was concerned with the lives of the great scientists themselves, the challenges they met, the struggles they faced, and the obstacles they overcame when they were successful. Not only are these stories of great intrinsic interest, but I believe there is no better way to stimulate the creative impulse than to learn at first hand from the words of the masters, those whose work has survived the test of time.

Who, for example, can fail to be inspired by reading, in his own words, Fermat's statement of his famous "Last Theorem" and his claim to have found a truly marvelous proof of this magnificent theorem? An additional bonus is the insight one gains into the process which guided Fermat to his remarkable and surprising conclusion. The fact that the problem itself eluded all attempts at solution for some 350 years, finally yielding in the 
most unexpected way, adds an appropriate air of mystery to this extraordinary tale. The proof itself must be regarded as a major mathematical triumph, if not the supreme mathematical gem, of the twentieth century.

I remember, too, with what pleasure I read, for example, Archimedes' account of his discovery of the volume and surface area of the sphere and of Gauss's proof, in his own words, of the constructibility, with straight edge and compass, of the regular polygon of 17 sides, totally unanticipated at the time. In both these cases I felt as if I were sharing in the joy of their discoveries, almost as if I were participating in the discovery process itself, a feeling which I think can be conveyed in no other way. I believe in fact that no third person account can possibly generate the same sensation of pleasure one derives by sharing with the author himself his own feelings of excitement as he recounts the circumstances of his discovery.

These examples then provide, in my opinion, convincing evidence that an important purpose is served by those who take upon themselves the task of scientific biography which attempts to throw light on the origins of discovery, as Professor Hargittai attempts to do in his book. I believe, too, that much of the earlier biographies which already exist were written after the death of the scientist involved, often long after, so that no first hand account is available. Then, too, these earlier biographies were often written by those with little or inadequate scientific background so that the circumstances and the full significance of the scientist's contribution were not always made clear.

Professor Hargittai's contribution, on the other hand, serves the unique and important purpose that it presents in a timely way, while the scientist himself is still alive, and in the first person, the significance of his contribution and the context in which it was made, as he himself has seen it. For this reason the reader himself feels a closer connection with the scientist than would otherwise be possible and develops a deeper appreciation of the author's contribution than he otherwise might. In any event this has been my own experience and I believe that Professor Hargittai's book will serve the same function, the importance of which cannot be exaggerated, since I believe it will stimulate the reader to think in new directions. 
This is the third volume of the Candid Science series and I have been gratified by the warm reception for the first two volumes. In this volume, I am returning to chemistry, but the classification in this collection is as free as in the previous two volumes. This collection contains again interviews with a diverse group of scientists. It covers a broad spectrum of research areas in chemistry, including the discovery of new elements and compounds, the VSEPR model, computational chemistry, organic synthesis, natural products, polysaccharides, supramolecular chemistry, peptide synthesis, combinatorial chemistry, $\mathrm{X}$-ray crystallography, reaction mechanism and kinetics, electron transfer in small and large systems, non-equilibrium systems, oscillating reactions, atmospheric chemistry, chirality, and the history of chemistry. The topics are discussed first-hand by, we think, the most appropriate persons.

Sometimes it happens that when one produces a book, it may stay on one's shelf after it has appeared in print, but I do not find this with the Candid Science volumes. I freely admit that I often return to them for information or just for reading. I consulted my interviews extensively when I was working on my later book about the Nobel Prize (The Road to Stockholm, Oxford University Press) and as I was preparing lectures for my course at the Budapest University of Technology and Economics, entitled "Great Discoveries in $20^{\text {th }}$ Century Science." This academic year, I am presenting the course for the fourth time and this provides an additional stimulus for continuing with my interviews. I can now see how our students absorb the stories about the discoveries and the human backgrounds of 
the great scientists of earlier times, which give life to the actual scientific papers.

My fascination with interviewing has not waned over the years. I never thought that one could get addicted to such activity, but apparently I did. I still prepare with the same curiosity and anticipation for my next interview as I did for the first. We are working on the fourth volume of the series (M. Hargittai, I. Hargittai, Candid Science IV: Conversations with Famous Physicists) and a fifth volume now seems to be emerging as well.

This volume contains more unpublished interviews than the previous volumes. For those published earlier, I express my appreciation to the now defunct magazine The Chemical Intelligencer (Springer Verlag, New York) and to the magazine, Chemical Heritage (Chemical Heritage Foundation, Philadelphia) for their kind cooperation.

I thank the enthusiastic staff of Imperial College Press (London) and of World Scientific (Singapore), and especially my editorial contact Mr. Suwarno, for their dedicated efforts in bringing out these volumes. I also thank Mr. István Fábri and Ms. Judit Szücs (both in Budapest) for untiring technical assistance. I am grateful for the generous support from the Hungarian Academy of Sciences and the Budapest University of Technology and Economics as well as for the support of our molecular structure research by the Hungarian National Scientific Research Foundation and the Ministry of Education of Hungary. Our scientific research brings us to meetings and laboratory visits whose byproducts are often the interviews presented here and elsewhere. Our family vacations provide additional opportunities in this respect.

Interactions with our children, Balazs, an Assistant Professor of Chemistry at St. Francis University in Loretto, Pennsylvania, and Eszter, a Ph.D. student in the Sociology of the Internet at Princeton University, have brought encouragement for these projects. My wife and fellow scientist, Magdi, Editor of these volumes, continues to be an inspiration. 


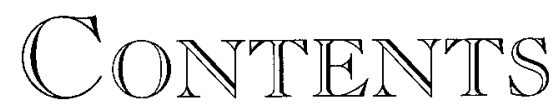

Foreword $\quad$ v

Preface vii

Glenn T. Seaborg $\quad 2$

William N. Lipscomb 18

$\begin{array}{lr}\text { Neil Bartlett } & 28\end{array}$

Ronald J. Gillespie $\quad 48$

Lawrence S. Bartell $\quad 58$

$\begin{array}{lr}\text { Paul von Ragué Schleyer } & 80\end{array}$

Albert Eschenmoser $\quad 96$

Gilbert Stork 108

$\begin{array}{ll}\text { Endre A. Balazs } & 120\end{array}$

$\begin{array}{ll}\text { Alfred Bader } & 146\end{array}$

$\begin{array}{ll}\text { Jacquelin K. Barton } & 158\end{array}$

$\begin{array}{ll}\text { Ad Bax } & 168\end{array}$

$\begin{array}{lr}\text { Donald J. Cram } & 178\end{array}$

$\begin{array}{ll}\text { Jean-Marie Lehn } & 198\end{array}$ 
x Hargittai, Candid Science III

$\begin{array}{lr}\text { Bruce Merrifield } & 206\end{array}$

$\begin{array}{lr}\text { Árpád Furka } & 220\end{array}$

$\begin{array}{ll}\text { Guy Ourisson } & 230\end{array}$

$\begin{array}{ll}\text { Mildred Cohn } & 250\end{array}$

$\begin{array}{lr}\text { Paul D. Boyer } & 268\end{array}$

$\begin{array}{lr}\text { John E. Walker } & 280\end{array}$

Herbert A. Hauptman $\quad 292$

$\begin{array}{ll}\text { Jack D. Dunitz } & 318\end{array}$

Hartmut Michel $\quad 332$

Johann Deisenhofer $\quad 342$

$\begin{array}{ll}\text { Robert Huber } & 354\end{array}$

Manfred Eigen $\quad 368$

$\begin{array}{ll}\text { John C. Polanyi } & 378\end{array}$

Dudley R. Herschbach $\quad 392$

Henry Taube $\quad 400$

$\begin{array}{ll}\text { Rudolph A. Marcus } & 414\end{array}$

Ilya Prigogine $\quad 422$

Anatol M. Zhabotinsky 432

$\begin{array}{ll}\text { Richard N. Zare } & 448\end{array}$

$\begin{array}{ll}\text { Paul J. Crutzen } & 460\end{array}$

Reiko Kuroda 466

$\begin{array}{ll}\text { Stephen Mason } & 472\end{array}$

$\begin{array}{ll}\text { Index } & 497\end{array}$ 